\title{
Functional reconstitution of wild-type and mutant Tetrahymena telomerase
}

\author{
Chantal Autexier and Carol W. Greider ${ }^{1}$ \\ Cold Spring Harbor Laboratory, Cold Spring Harbor, New York 11724 USA
}

Telomerase is a ribonucleoprotein that catalyzes telomere elongation in vitro and in vivo. The 159-nucleotide RNA component of Tetrahymena telomerase contains the sequence 5'-CAACCCCAA-3' ("template region"), which serves as a template for the addition of the sequence d(TTGGGG) $)_{\mathbf{n}}$ to Tetrahymena telomeres. To dissect the Tetrahymena telomerase enzyme mechanism, we developed a functional in vitro reconstitution assay. After removal of the essential telomerase RNA by micrococcal nuclease digestion of partially purified telomerase, the addition of in vitro-transcribed telomerase RNA reconstituted telomerase activity. The reconstituted activity was processive and showed the same primer specificities as native telomerase. Mutants in the RNA template region were tested in reconstitution assays to determine the role of the residues in this region in primer recognition and elongation. Two template mutants, encoding the sequences $5^{\prime}$-UAACCCCAA-3' and 5'-UAACCCUAA-3', specified the incorporation of dATP into the sequence d(TTAGGG). Telomerase reconstituted with a template mutant encoding the sequence $5^{\prime}$-CAACCCUAA-3' did not specify dATP incorporation and elongation by this mutant was not terminated by the addition of ddATP. In addition, a template mutant encoding the sequence 5'-CGGCCCCAA-3' specified the incorporation of ddCTP but not ddTTP while a mutant encoding the sequence 5'-CAACCCCGG-3' specified the incorporation of ddTTP but not ddCTP. These data suggest that only the most 5 ' six residues of the template region dictate the addition of telomeric repeats.

[Key Words: Telomeres; telomerase; reconstitution; ribonucleoprotein; Tetrahymena; micrococcal nuclease]

Received November 22, 1993; revised version accepted January 13, 1994.

The maintenance of telomere length is vital to the integrity of chromosomes and the survival of cells. One mechanism by which telomere length is maintained in eukaryotes is by the de novo addition of sequences onto chromosome ends by the enzyme telomerase (for review, see Blackburn 1991). Tetrahymena telomerase is a ribonucleoprotein (RNP) enzyme that synthesizes the telomeric sequence $d(\text { TTGGGG })_{n}$ comprising the ends of Tetrahymena chromosomes (Greider and Blackburn 1987). The 159-nucleotide RNA component of Tetrahymena telomerase contains the sequence 5'-CAACCCCAA-3' ("template region"), which serves as an internal template for the addition of telomeric sequence repeats (Greider and Blackburn 1989). When altered telomerase RNA genes, encoding mutations in the template region of telomerase RNA, were introduced into Tetrahymena, altered telomere sequences were synthesized that corresponded to the mutated RNA sequences, indicating that the template region directs the synthesis of telomeric repeats (Yu et al. 1990).

In vitro, Tetrahymena telomerase can processively elongate telomeric substrates generating a distinct six nucleotide banding pattern (Greider and Blackburn 1985). The strongly labeled product within the repeat

\footnotetext{
${ }^{1}$ Corresponding author.
}

pattern represents a pause in elongation after the addition of the first $G$ residue in the sequence GGGGTT (Greider 1991a). Following this pause, which occurs at the extreme $5^{\prime}$ end of the template region, the enzyme translocates to initiate another round of telomeric repeat synthesis (Greider and Blackburn 1989). The sequence at the 3' end of telomeric substrates specifies the first nucleotide added in elongation reactions with telomerase. For example, a $G$ residue will first be added to a telomeric primer ending in the sequence $\mathrm{d}$ (GGGGTT) while a $T$ residue will be added to a primer ending in the sequence d(TTGGGG) (Greider and Blackburn 1987; Zahler and Prescott 1988; Morin 1989; Shippen-Lentz and Blackburn 1989|. Tetrahymena telomerase also catalyzes a specific nucleolytic activity that cleaves substrates containing the telomeric repeat d(GGGTTG) at the 3' end (Collins and Greider 1993). Telomerase activity has also been identified in the ciliates Euplotes and Oxytricha and in immortalized human and mouse cell lines (Zahler and Prescott 1988; Morin 1989; ShippenLentz and Blackburn 1989; Counter et al. 1992; Prowse et al. 1993). However, only the RNA components of Tetrahymena and Euplotes telomerase have been identified to date (Greider and Blackburn 1989; Shippen-Lentz and Blackburn 1990).

The presence of short tandem repeats of simple G-rich 
sequences at the ends of chromosomes is highly conserved in eukaryotes, suggesting conserved function, and/or synthesis of telomeres (for reviews, see Zakian 1989; Blackburn 1991; Greider 1991b; Biessmann and Mason 1992). Telomeres are essential for providing stability to chromosomes. Broken chromosomes that lack telomeres are generally unstable and contribute to genome rearrangements (Müller 1938; McClintock 1941; Biessmann and Mason 1992). Telomeres also ensure the complete replication of linear chromosomes. The addition of sequences by telomerase may balance sequence loss due to the incomplete replication of chromosome ends by conventional DNA polymerases (Watson 1972; Olovnikov 1973).

In Tetrahymena cells expressing mutant telomerase RNAs, altered telomere sequences and lengths result in nuclear and cell division defects, and senescence /Yu et al. 1990). Yeast est1 mutants that lose telomeric sequences with each round of replication also have a senescence phenotype (Lundblad and Szostak 1989). When primary mammalian cells are passaged in vitro, telomere length decreases and the cells senesce (Harley et al. 1990). A similar shortening in telomere length is seen in vivo; fibroblast and lymphocyte telomere lengths decrease as humans age (Allsopp et al. 1992; Vaziri et al. 1993). Telomerase has been identified in many immortalized human and mouse cell lines but not in most primary cells tested to date (Morin 1989; Counter et al. 1992; Prowse et al. 1993). These data suggest that telomerase activity may be absent in primary cells and may be required for the growth of immortalized cells (Harley et al. 1990; Hastie et al. 1990; Prowse et al. 1993). To understand the role of telomerase in senescence and immortalization it is essential to elucidate the mechanism of telomerase action in the maintenance of telomere length.

To understand telomerase function we are analyzing the mechanism and components of this unusual RNP. RNPs play important roles in vital cellular processes such as protein biosynthesis, RNA splicing and processing, and protein translocation. The reconstitution of $\mathrm{r}$ bosomes, ribonuclease $\mathrm{P}$, signal recognition particle (SRP), small nuclear RNPs (snRNPs), heterogenous nuclear RNP and human mitochondrial RNA processing RNP (MRP) has facilitated a detailed understanding of the structure, function and assembly of these enzymes (Traub and Nomura 1969; Nierhaus and Dohme 1974; Kole and Altman 1979; Walter and Blobel 1983; McPheeters et al. 1989; Schenkel and Kloetzel 1989). To dissect Tetrahymena telomerase we developed a functional in vitro reconstitution assay. The addition of in vitro-transcribed telomerase RNA to micrococcal nuclease (MNase)-inactivated telomerase reconstituted activity. Analysis of telomerase activity reconstituted with telomerase RNAs mutated in the template region suggests that only the most $5^{\prime}$ six nucleotides in the sequence $5^{\prime}$-CAACCCCAA- $3^{\prime}$ specify nucleotide sequence addition. The ability to reconstitute telomerase activity from isolated RNA and protein components will facilitate the identification of telomerase protein subunits and the detailed functional dissection of this RNP.

\section{Results \\ Reconstitution of telomerase activity after MNase digestion}

The integrity of many RNPs is dependent on the presence of divalent cations. Chelating agents such as EDTA have been successfully employed to partially unfold a number of RNPs including ribosomal subunits, RNase $P$, small cytoplasmic RNPs and SRP, which were subsequently disassembled into protein and RNA components by column chromatography (Blobel 1971; Spirin 1974; Newton et al. 1975; Guthrie and Atchison 1980; Mukheriee and Sarkar 1981; Walter and Blobel 1983). To address the effect of EDTA on reconstitution of telomerase activity, we first treated partially purified active telomerase fractions with $\mathrm{Ca}^{2+}$ and MNase to remove endogenous telomerase RNA. After incubation, MNase was inactivated by chelating $\mathrm{Ca}^{2+}$ with EGTA. Following nuclease digestion no telomerase RNA could be detected by Northern analysis (data not shown) and telomerase activity was abolished (Fig. 1; Greider and Blackburn 1987). Activity was restored by incubating MNasetreated telomerase with $5 \mathrm{~mm}$ EDTA and $100 \mathrm{ng}$ of in vitro transcribed telomerase RNA, followed by the addition of $\mathrm{Mg}^{2+}$. Reconstitution of telomerase activity specifically required the addition of Tetrahymena telomerase RNA. Activity was not restored without RNA nor with several nonspecific RNAs. The addition of excess amounts of nonspecific RNA did not lower the requirement for telomerase RNA (Fig. 1).

To investigate the role of RNA secondary structure on reconstitution of telomerase activity, telomerase RNA was heated to $65^{\circ} \mathrm{C}$ and cooled slowly to room temperature before adding it to reconstitution reactions. This treatment did not stimulate or inhibit the level of reconstituted activity (data not shown). Reconstitution of telomerase activity was optimal at $37^{\circ} \mathrm{C}$ for short incubation times $(5-10 \mathrm{~min})$. Longer incubation times (15-20 min) or incubation at lower $\left(30^{\circ} \mathrm{C}\right)$ or higher $\left(42^{\circ} \mathrm{C}\right)$ temperatures decreased the levels of reconstituted telomerase activity (data not shown). Pretreatment of the extract with proteinase $K$ abolished reconstitution of telomerase activity indicating that a protein component $(s)$ is required for reconstitution of activity (Fig. 1).

\section{Reconstitution of primer specificity and cleavage}

To further characterize reconstituted enzyme activity we tested the primer specificity of this activity. No elongation of a nontelomeric pBR primer (Fig. 1; Harrington and Greider 1991) was detectable with the reconstituted extract, and no products were generated in the absence of a specific primer oligonucleotide (Fig. 1). This specificity for a telomeric primer is identical to that seen with native telomerase (Greider and Blackburn 1985). Moreover, incorporation of $\left[\alpha^{-32} \mathrm{P}\right] \mathrm{dGTP}$ onto the telomeric primer d(GGGGTT) $)_{3}$ was sensitive to pretreatment with RNase A (data not shown) as expected for telomerase (Greider and Blackburn 1987).

Elongation of telomeric primers by Tetrahymena te- 


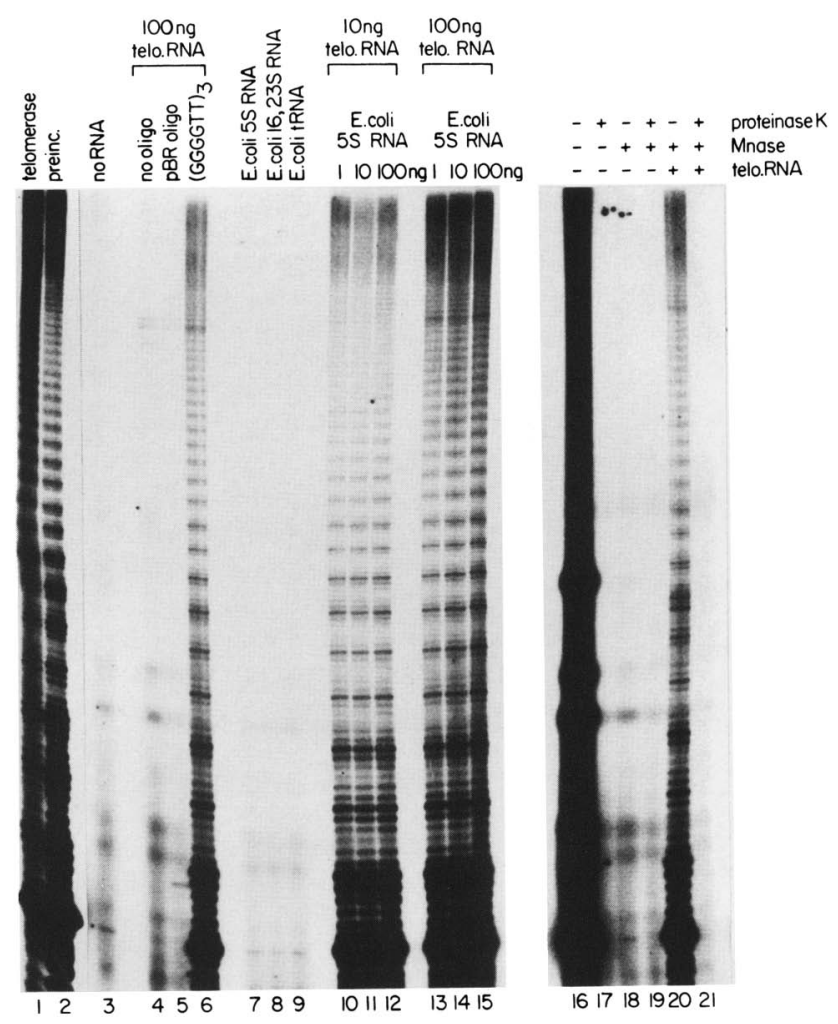

Figure 1. Reconstitution of telomerase activity after MNase treatment. Telomerase assays were performed with telomerase pretreated as indicated. (Lane 1) DEAE-purified telomerase; (lane 2) DEAE-purified telomerase, preincubated under similar buffer conditions as reconstitution reactions. (Lanes 3-15) Telomerase reconstituted with various RNAs-without RNA (lane 3), with $10 \mathrm{ng}$ of telomerase RNA (lanes 10-12), or with $100 \mathrm{ng}$ of telomerase RNA (lanes $4-6,13-15,20,21$ ). E. coli $5 \mathrm{~S}$ rRNA (Boehringer Mannheim) was added as a nonspecific competitor: $1 \mathrm{ng}$ (lanes 10,13), $10 \mathrm{ng}$ (lanes 11,14), or $100 \mathrm{ng}$ (lanes 12,15). Control reconstitution assays with nonspecific RNAs: $100 \mathrm{ng}$ of E. coli $5 \mathrm{~S}$ rRNA (lane 7), E. coli 16 and 23S rRNA (Sigma; lane 8), or E. coli tRNA (lane 9). Oligonucleotides used

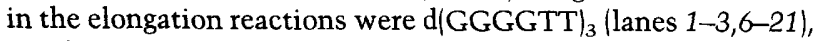
no oligonucleotide (lane 4), pBR oligonucleotide (sequence, $5^{\prime}$ AGCCACTATCGACTACGCGATCAT-3'; Harrington and Greider 1991; lane 5). (Lanes 16-21) Telomerase pretreated with proteinase $\mathrm{K}$ as described. Lanes 1 and 2 are from a lighter exposure than the other lanes ( $20 \mathrm{hr}$ vs. 14 days). In equivalent exposures these lanes were too dark to distinguish the banding pattern.

lomerase generates a distinct 6-nucleotide repeat pattern. A strongly labeled product within this repeat corresponds to a pause after the addition of the first $G$ residue in the sequence d(GGGGTT) ${ }_{n}$ (Greider 1991a). The sequence at the $3^{\prime}$ end of telomeric primers specifies the first nucleotide added in elongation reactions with telomerase and the number of nucleotides added before pausing occurs (Greider and Blackburn 1987). To confirm that the reconstituted activity was attributable to telomerase, and to test the telomeric primer specificity of the reconstituted activity, five different 18-base oligonucle- otide permutations of the sequence $\mathrm{d}(\mathrm{GGGGTT})_{3}$ were used in the elongation assay (Fig. 2A). A light exposure of the data is shown so that the initial repeats in lanes 4-18 can be clearly distinguished. A darker exposure of the $\mathrm{d}\left(\right.$ GGGGTT) ${ }_{3}$ elongation products is shown in lanes 1921 to illustrate that long products are generated in these reactions. Figure $2 \mathrm{~B}$ illustrates the products expected from the predicted alignment of the primers with the telomerase RNA template. Elongation of the telomeric primer d(GGGGTT) 3 by reconstituted telomerase paused after the addition of the first $\mathrm{dG}(+1)$ in the sequence GGGGTT, and every 6 nucleotides after the first $\mathrm{dG}(+7)$, as expected for telomerase. Elongation of the telomeric primer d(GGGTTG) ${ }_{3}$ generated a strongly labeled product corresponding to the addition of 6 nucleotides, GGGTTG $(+6)$ to the 3 ' end of the primer, representing the first $\mathrm{G}$ residue in the sequence GGGGTT. There was also a labeled product at the position corresponding to the size of the input telomeric primer $(\mathrm{P})$, because of the cleavage activity of telomerase (Collins and Greider 1993; see below). Elongation of the permuted primers $\mathrm{d}\left(\mathrm{GGTTGG}_{3}, \mathrm{~d}\left(\mathrm{GTTGGG}_{3}\right.\right.$ and $\mathrm{d}(\mathrm{TTG}$ GGG $\left.\right|_{3}$ by reconstituted telomerase also generated the correct sequence specific pauses expected for native telomerase and in each case the position of the strongly labeled product was consistent with pausing at the first $\mathrm{G}$ residue in the sequence GGGGTT.

Dideoxynucleotides (ddNTPs) were used to determine the nucleotide sequence added onto the telomeric primers (Fig. 2). Substitution of ddTTP for dTTP in elongation assays generated specific chain termination products. Elongation of the permuted telomeric primers d(GGGGTT) $)_{3}$, d(GGGTTG) $)_{3}$, d(GGTTGG) $)_{3}$, and d(GTTGGG) $)_{3}$ was terminated after the addition of $5,4,3$, and 2 nucleotides, respectively. The lengths of the products generated upon incorporation of ddTTP suggested that reconstituted telomerase has similar primer specificities to native telomerase. As a control for ddTTP addition in these experiments, ddCTP was added to telomerase assays. The addition of low concentrations of ddCTP does not alter native telomerase activity as there are no $G$ residues in the wild-type template region /Greider and Blackburn 1985), and similarly had no effect on reconstituted enzyme activity.

Tetrahymena telomerase possesses a specific nucleolytic activity that cleaves primers containing the telomeric repeat d(GGGTTG) at the $3^{\prime}$ end (Collins and Greider 1993). The G residue at the $3^{\prime}$ end of these primers can align with the $C$ residue at the extreme $5^{\prime}$ end of the RNA template. During cleavage, the 3 '-terminal G residue is removed and a single $\left[\alpha^{-32} \mathrm{P}\right] \mathrm{dGTP}$ is added. The primer specificity of the telomerase cleavage reaction is reconstituted with synthetic telomerase RNA (Fig. 2A).

\section{Reconstitution of telomerase activity with mutant RNA template sequences}

To determine whether mutant RNAs could be used in the reconstitution assay and to dissect the role of the 


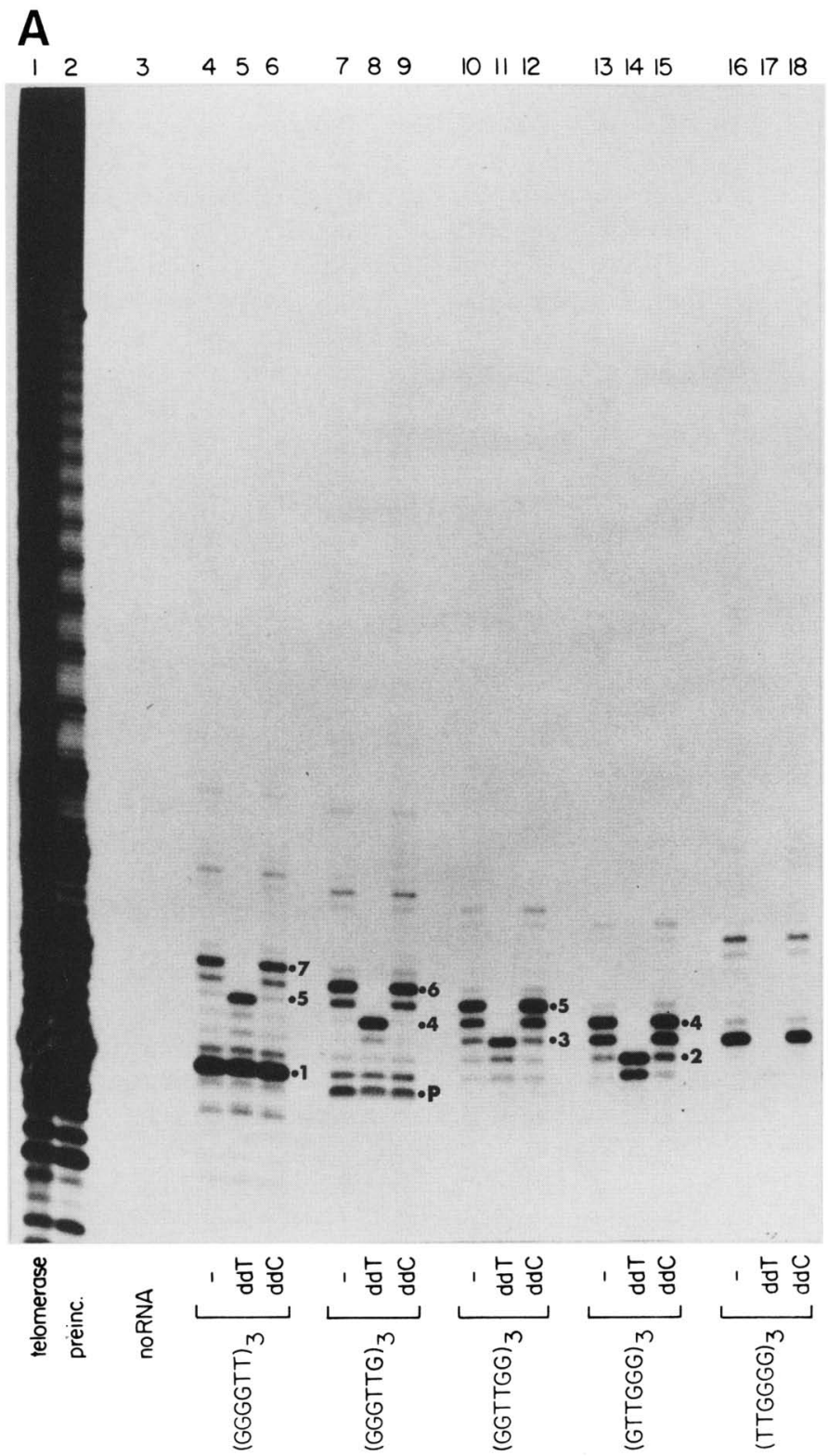

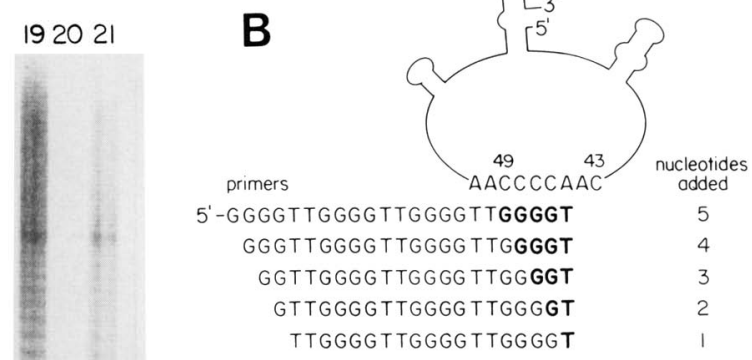

Figure 2. Reconstitution of primer specificity and cleavage. $(A)$ Telomerase assays were performed with telomerase pretreated as indicated. (Lane 1) DEAE-purified telomerase; (lane 2): DEAE-purified telomerase preincubated under similar buffer conditions as reconstitution reactions; (lane 3) telomerase reconstituted with no RNA. The primer d(GGGGTT) $)_{3}$ was used in lanes 1-3 (Lanes 4-21) Permutations of Tetrahymena telomeric oligonucleotides were used to assay the elongation activity of DEAE-purified telomerase reconstituted with telomerase RNA (200 ng): d/GGGGTT) ${ }_{3}$ (lanes 4-6, 19-21), d(GGGTTG) (lanes 7-9), d(GGTTGG) $_{3}$ (lanes 10-12), d(GTTGGG) (lanes

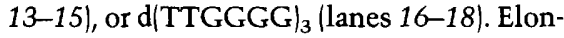
gation reactions were carried out in the presence of $\left[\alpha^{-32} \mathrm{P}\right] \mathrm{dGTP}$ and dTTP (lanes $4,7,10,13,16,19], \quad\left[\alpha^{-32}\right.$ P]dGTP and ddTP (lanes $5,8,11,14,17,20)$, or $\left[\alpha^{-32} \mathrm{P}\right] \mathrm{dGTP}$, dTTP and ddCTP (lanes $6,9,12,15,18,21)$ as described. Lanes 19-21 are a darker exposure of the reactions in lanes $4-6$ to show that long products were synthesized. The numbers indicate the number of nucleotides added onto the input primers. $(\mathrm{P})$ The size of the 18-mer input primer. $(B)$ Schematic diagram of the template region of telomerase RNA (modified from Romero and Blackburn 1991) aligned with the primers tested in $A$. Nucleotides in bold represent nucleotides added onto the $3^{\prime}$ end of the primers before and including the addi-

tion of ddTTP. For simplicity the primer d(GGGGTT) $)_{3}$ was aligned as shown. More correctly, the primer should be aligned at the $5^{\prime}$ end of the template region, a $\mathrm{G}$ residue added, and then aligned as shown subsequent to a translocation of the primer from the $5^{\prime}$ end of the template region to the $3^{\prime}$ end.

template region in the recognition and elongation of telomeric substrates, five mutant DNA templates were constructed. The template region of the cloned Tetrahy. mena telomerase RNA gene was altered by site-directed mutagenesis of a $\mathrm{C} \rightarrow \mathrm{T}$ residue at positions 43,49 , and both 43 and 49 . The resulting RNA template sequences were 5'-UAACCCCAA-3' (43U), 5'-CAACCCUAA-3' (49U), and 5'-UAACCCUAA-3' (4349U). These three mutants were initially used because they could potentially specify the synthesis of vertebrate d(TTAGGG) telomeric repeats and Tetrahymena telomerase will bind and elongate primers of this sequence (Greider and Blackburn 1987). Two additional template mutants were constructed by changing the A residues at positions 44 and 45 or positions 50 and 51 to $G$ residues. The RNA template sequences were 5'-CGGCCCCAA-3' (4445G) and 5'-CAACCCCGG-3' (5051G).

Three mutant RNAs (43U, 49U, and 4349U) reconstituted telomerase activity when assayed in the presence of $\left[\alpha^{-32}\right.$ P $]$ dGTP, dATP, dTTP, and d(GGGGTT) $]_{3}$ (Fig. 3A). However, in the absence of dATP, elongation was most significantly impaired by telomerase enzyme reconstituted with $4349 \mathrm{U}$ mutant RNA suggesting that one or both $U$ residues are required for template-directed synthesis of telomeric repeats. Elongation was more processive with telomerase reconstituted with 4349U RNA 


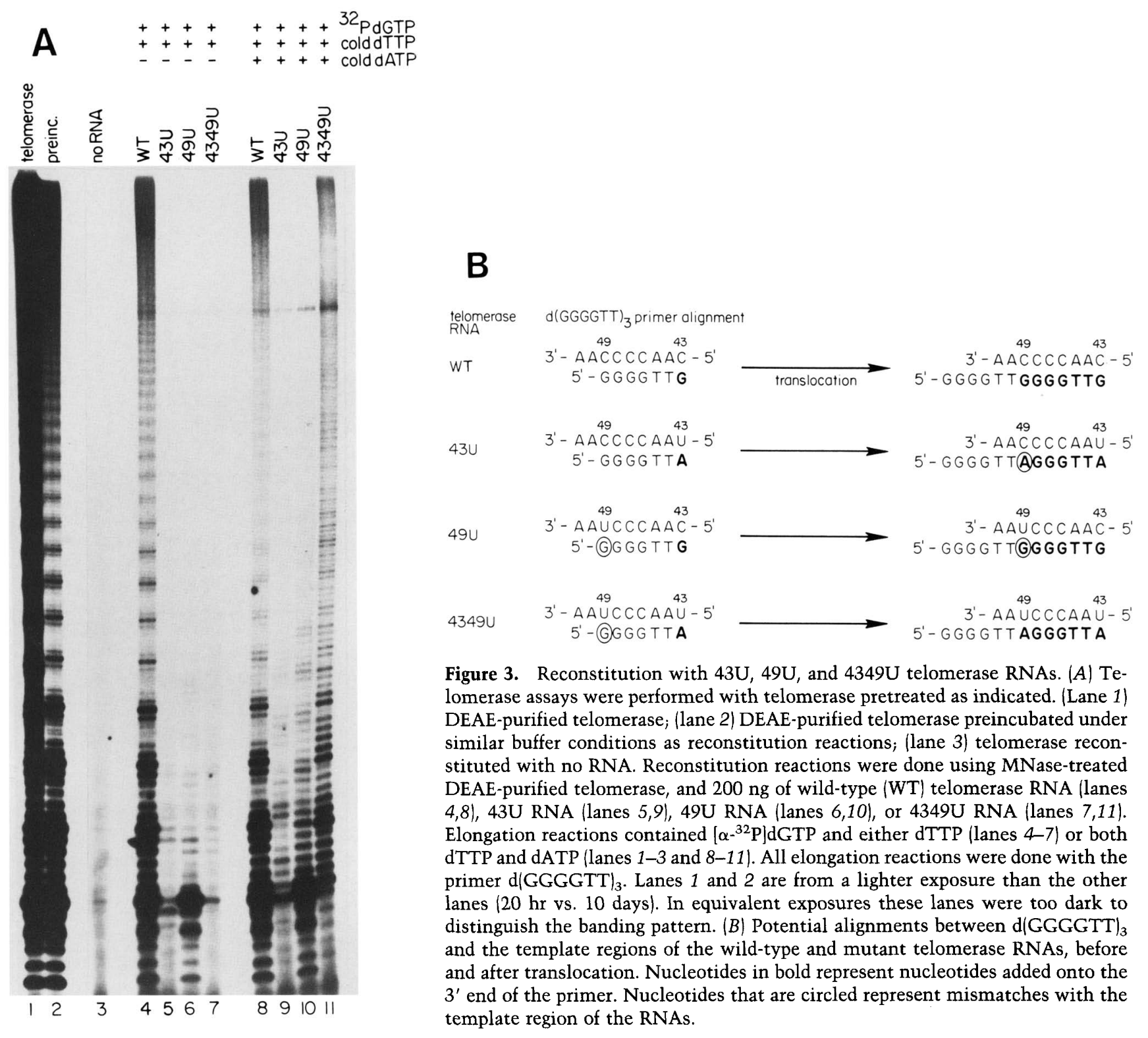

than with $43 \mathrm{U}$ or $49 \mathrm{U}$ RNA, possibly because of mismatches between the primer and templates of the $43 \mathrm{U}$ and $49 \mathrm{U}$ mutant RNAs (Fig. 3B). A less distinct than wild-type banding pattern was generated by telomerase reconstituted with $4349 \mathrm{U}$ RNA, suggesting that the product sequence may have effects on telomerase enzyme mechanisms such as substrate recognition, binding affinity, and processivity. Figure $3 \mathrm{~B}$ illustrates the potential alignments of primer d(GGGGTT) ${ }_{3}$ with the template regions of the telomerase RNAs tested, highlighting possible mismatches (circled nucleotides) prior to and following the first translocation. Upon subsequent translocations, mismatches would arise between the product DNA and the template regions of $43 \mathrm{U}$ and 49U RNA, possibly inhibiting processive elongation. However, after the first addition reaction, no mismatches would occur between the product DNA and the template region of $4349 \mathrm{U}$ RNA, thereby allowing processive elongation.

To confirm that dATP was incorporated into the elongation products described above, telomerase assays were performed using $\left[\alpha-{ }^{32} \mathrm{P}\right] \mathrm{dATP}$ (Fig. 4A). At a concentration of $2.5 \mu \mathrm{M},\left[\alpha^{-32} \mathrm{P}\right] \mathrm{dATP}$ was not incorporated by telomerase reconstituted with wild-type or 49U RNA but was incorporated by telomerase reconstituted with the $43 \mathrm{U}$ and the $4349 \mathrm{U}$ mutants, indicating that the $U$ at position 43 of these mutant RNAs serves as a template. To test whether telomerase reconstituted with $49 \mathrm{U}$ RNA might incorporate $\left[\alpha^{-32} \mathrm{P}\right] \mathrm{dATP}$, and to determine whether incorporation of $\left[\alpha^{-32} \mathrm{P}\right] \mathrm{dATP}$ by telomerase reconstituted with $43 \mathrm{U}$ and $4349 \mathrm{U}$ RNA might be increased, higher concentrations of $\left[\alpha^{-32} \mathrm{P}\right] \mathrm{dATP}(7.5 \mu \mathrm{M})$ were used. This higher concentration did not result in incorporation of $\left[\alpha^{-32} \mathrm{P}\right] \mathrm{dATP}$ by telomerase reconsti- 
A
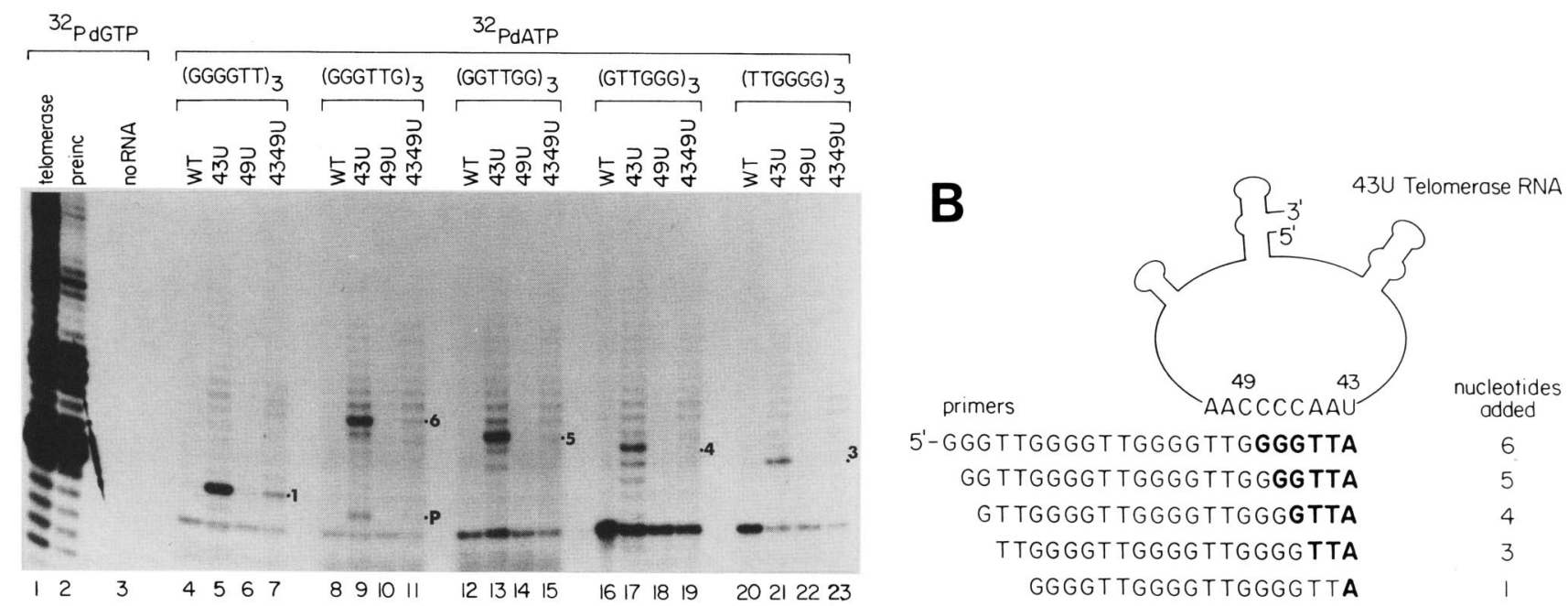

Figure 4. Incorporation of $\left[\alpha-{ }^{32} \mathrm{P}\right] \mathrm{dATP}$ by telomerase reconstituted with mutant telomerase RNAs. $(A)$ Telomerase assays were performed with telomerase pretreated as indicated. (Lane 1) Phenyl-Sepharose-purified telomerase; (lane 2) phenyl-Sepharose-purified telomerase preincubated under similar buffer conditions as reconstitution reactions; (lane 3) telomerase reconstituted with no RNA. The primer d(GGGGTT $\left.\right|_{3}$ and $\left[\alpha^{-32} \mathrm{P} \mid \mathrm{dGTP}\right.$ were used in telomerase reactions in lanes $1-3$. Telomerase reconstituted with $200 \mathrm{ng}$ of wild-type (WT) telomerase RNA (lanes $4,8,12,16,20$ ), 43U RNA (lanes 5,9,13,17,21), 49U RNA (lanes $6,10,14,18,22$ ) or 4349U RNA

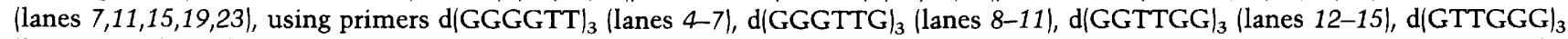

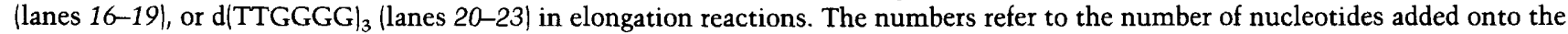
input primers $(\mathrm{P})$. The labeled product of 17 bases was a nonspecific contaminant. $(B)$ Schematic diagram of predicted alignments between $43 \mathrm{U}$ telomerase RNA and telomeric primers. Nucleotides in bold represent nucleotides added before and including the incorporation of $\left[\alpha^{-32} \mathrm{P}\right] \mathrm{dATP}$.

tuted by $49 \mathrm{U}$ RNA (data not shown). Enzyme reconstituted with the $43 \mathrm{U}$ mutant RNA specified the incorporation of $\mathrm{dATP}$ at the correct position within the telomeric repeat (Fig. 4A and B). The d(GGGGTT) 3 primer apparently aligned with the template such that the first nucleotide added $\left(\left[\alpha^{-32} \mathrm{P}\right] \mathrm{dATP} ;+1\right)$ was template-directed by the $U$ at position 43 in the RNA. The position of strong pausing or incorporation of $\left[\alpha^{-{ }^{32}} \mathrm{P}\right] \mathrm{dATP}$ was 6 nucleotides $(+6)$ from the $3^{\prime}$ end of the telomeric primer d(GGGTTG) $)_{3}$. Similarly, a predominant $\left[\alpha^{-32}\right.$ P]dATP-labeled product was present at positions 5,4 , and 3 nucleotides from the $3^{\prime}$ end of the primers, $d(G G T T G G)_{3}$, $\mathrm{d}(\text { GTTGGG })_{3}$, and d(TTGGGG) $)_{3}$, respectively. A strongly labeled product was also present at a position corresponding to the size of the input d(GGGTTG) $\left.\right|_{3}$ primer $(\mathrm{P})$, presumably because of primer cleavage at the $3^{\prime}$ terminus and addition of $\left[\alpha^{-32} \mathrm{P}\right] \mathrm{dATP}$. With all oligonucleotide permutations, a less intense product was generated at the position of $\left[\alpha^{-32} \mathrm{P}\right] \mathrm{dATP}$ incorporation by telomerase reconstituted with $4349 \mathrm{U}$ RNA compared with $43 \mathrm{U}$, suggesting that pausing or dissociation occurs less frequently in this mutant. The experiments illustrated in Figures 3 and 4 indicate that dATP is incorporated into elongation products generated by telomerase reconstituted with $43 \mathrm{U}$ and $4349 \mathrm{U}$ RNA, but not $49 \mathrm{U}$, suggesting that position 43 of the telomerase template region specifies the incorporation of nucleotides into telomeric DNA products.

When $\mathrm{d}(\mathrm{GTTGGG})_{3}$ was used as a primer in telo- merase assays with $\left[\alpha{ }^{32} \mathrm{P}\right] \mathrm{dGTP}$, elongation by telomerase reconstituted with $49 \mathrm{U}$ or $4349 \mathrm{U}$ RNA was not as efficient when compared with activity reconstituted with wild-type or $43 U$ RNA (data not shown). Inefficient elongation of $\mathrm{d}(\mathrm{GTTGGG})_{3}$ by telomerase reconstituted with $49 \mathrm{U}$ or $4349 \mathrm{U}$ RNA suggested that mismatches, alignment of primer sequences at more than one position within the template, and/or template slippage might be occurring. Two sites have been proposed for the recognition of telomeric primers (Collins and Greider 1993). One site, presumed to reside in the template region of the RNA, binds the most $3^{\prime}$ telomeric repeat of the primer or product DNA. The other site may be a protein component which binds residues $5^{\prime}$ of, and adjacent to, the sequences bound to the RNA. This model predicts that changing the template sequence of the RNA would alter the binding specificity to the RNA but not to the protein. To optimize primer binding and alignment of telomerase reconstituted with $49 \mathrm{U}$ or $4349 \mathrm{U}$ RNA, the chimeric oligonucleotide, d(GTTGGG) ${ }_{2}$ GTTAGG, was used in telomerase assays. This oligonucleotide has wild-type Tetrahymena telomeric repeat sequences at the $5^{\prime}$ end for wild-type binding specificity to the protein and mutant Tetrahymena telomeric repeat sequences at the $3^{\prime}$ end for binding to mutant template RNA sequences. Telomerase reconstituted with $49 \mathrm{U}$ or $4349 \mathrm{U}$ RNA elongated this oligonucleotide efficiently. Telomerase reconstituted with wild-type or 43U RNA did not elongate this oligonucleotide efficiently (data not 
shown), presumably because of mismatches that would occur between the template region of these RNAs and sequences at the $3^{\prime}$ end of this primer. Thus, in the experiments described below d(GTTGGG) ${ }_{3}$ was used to assay telomerase reconstituted with wild-type or $43 \mathrm{U}$ RNA, and d(GTTGGG) ${ }_{2}$ GTTAGG was used to assay telomerase reconstituted with $49 \mathrm{U}$ or $4349 \mathrm{U}$ RNA.

To determine the sequence of the nucleotides added by telomerase reconstituted with $43 \mathrm{U}, 49 \mathrm{U}$, and $4349 \mathrm{U}$ RNAs, telomerase reactions were performed using d/GTTGGG $)_{3}$ or d(GTTGGG $)_{2}$ GTTAGG, $\left[\alpha^{-}{ }^{32} \mathrm{P}\right] \mathrm{dGTP}$ and either ddATP and dTTP or ddTTP and dATP. As a control, reactions were performed with $\left[\alpha^{-32} \mathrm{P}\right] \mathrm{dGTP}$, ddCTP, dATP, and dTTP (Fig. 5A). The products of these reactions were compared to elongation of $d(G T T G G G)_{3}$ or $\mathrm{d}\left(\right.$ GTTGGG) ${ }_{2}$ GTTAGG in the presence of $\left[\alpha-{ }^{32} \mathrm{P}\right] \mathrm{dGTP}$, dATP, and dTTP. Elongation by telomerase reconstituted with wild-type RNA was not inhibited by ddATP, as expected, as there are no $U$ residues in the wild-type template region. Incorporation of ddTTP occurred 2 nucleotides from the $3^{\prime}$ end of the primer at the correct position (see Fig. 2B). Telomerase reconstituted with 43U RNA incorporated both ddATP and ddTTP, 4 and 2 nucleotides from the $3^{\prime}$ end of the primer, at the expected positions if the presumed template region, including position 43 , was specifying the nucleotides added. In the control reactions the addition of ddCTP did not alter telomerase activity. Using the chimeric oligonucleotide, elongation by $49 \mathrm{U}$ mutant telomerase was not inhibited by ddATP, suggesting that position 49 of the template region may not serve as a template (Fig. 5A). Using telomerase reconstituted with 4349U RNA, elongation in the presence of ddATP was terminated 4 nucleotides $(+4)$ from the $3^{\prime}$ end of the primer, as expected if position 43 is serving as a template. Incorporation of ddTTP occurred 2 nucleotides from the $3^{\prime}$ end of the primer, as expected from the predicted alignment of this primer with the $49 \mathrm{U}$ and $4349 \mathrm{U}$ RNA templates. Elongation was not inhibited in the presence of ddCTP. These data suggest that, under the conditions described, position 43 but not 49 in the template region of telomerase RNA dictates the addition of nucleotides onto telomeric substrates.

Further evidence for functional specialization within the template region was obtained using RNA mutant 4445G (5'-CGGCCCCAA-3') or 5051G (5'-CAACCCCGG-3') (Fig. 5B,C). To determine whether the mutant $G$ residues specified the incorporation of $\mathrm{dCTP}$, telomerase reactions were performed in the presence or absence of either dCTP or ddCTP. In addition, ddTTP was used to determine the template positions at which dTTP was specified (Fig. 5B). Telomerase reconstituted with the $4445 \mathrm{G}$ mutant generated a 5 nucleotide addition product using the primer $\mathrm{d}(\mathrm{GGTTGG})_{3}$ and either $\left[\alpha^{-32} \mathrm{P}\right] \mathrm{dGTP}$ and dCTP or $\left[\alpha^{-32} \mathrm{P}\right] \mathrm{dGTP}, \mathrm{dCTP}$, and dTTP (Fig. 5B lanes 6,7). However, when dCTP was omitted full-length elongation was not observed (Fig. 5B, lane 5). This suggested that dTTP was not necessary for elongation to the end of the template; however, dCTP was required. The strong pause or termination after elongation to the end of the template $(+5)$ may be attributable to inefficient translocation because of the mismatches generated between the newly formed DNA product and the RNA template region. The $4445 \mathrm{G}$ mutant telomerase incorporated ddCTP, 3 nucleotides $(+3)$ from the $3^{\prime}$ end of the primer (Fig. 5B, lane 9). Some readthrough to position +5 was also observed, probably because of some contamination of the reaction with dCTP. However, no incorporation of ddTTP was observed (Fig. 5B, lane 8). If the $A$ residues at position 50 or 51 were template nucleotides, ddTTP should be incorporated by telomerase reconstituted with $4445 \mathrm{G}$ RNA. These data suggest that the $\mathrm{G}$ residues at positions 44 and 45 dictate the addition of nucleotides but that the $\mathrm{A}$ residues at positions 50 and 51 do not.

The pattern of d(GGTTGG) $)_{3}$ elongation with the $5051 \mathrm{G}$ mutant further supported the interpretation of specialization within the template region. The overall level of elongation with this mutant is low probably attributable to the T-G mismatch in the initial alignment of primer and template (Fig. 5C). Elongation of d(GGTTGG) $)_{3}$ by the $5051 \mathrm{G}$ mutant telomerase with $\left[\alpha^{-32}\right.$ P]dGTP in the absence or presence of ACTP generated products with up to 5 residues added onto the 3 ' end (Fig. 5B, lanes 1,2). When ddTTP was added, elongation terminated after addition of only 3 residues (Fig. 5B, lane 3 ), as expected if the residue at position 45 is dictating the addition of dTTP. However, no incorporation of ddCTP was observed (Fig. 5B, lane 4), again suggesting that positions 50 and 51 of the telomerase RNA do not serve as template nucleotides.

\section{Discussion}

\section{Reconstitution of telomerase activity}

Telomerase is an unusual RNP polymerase that plays a vital role in the maintenance of chromosome ends. To understand in detail the mechanism of this RNP we have developed a functional reconstitution assay. Partially purified Tetrahymena telomerase was treated with MNase to remove the endogenous telomerase RNA component. Activity was reconstituted by the addition of EDTA and in vitro-transcribed telomerase RNA (Fig. 1). Studies on ribosomes suggest that EDTA does not cause the disassembly of ribosomes into RNA and protein, because after treatment the RNA and protein cosediment on sucrose gradients. Rather EDTA alters the specificity of the protein-RNA interaction such that proteins are free to move from one RNA strand to another (Newton et al. 1975). Thus, the addition of EDTA during reconstitution of telomerase activity may stimulate the interaction between inactivated MNase-treated telomerase and exogenously added synthetic telomerase RNA. Upon the addition of $\mathrm{Mg}^{2+}$, protein and RNA components may associate into an active complex. Reconstituted telomerase activity had similar properties to native telomerase activity including processivity, primer specificity, and RNase A sensitivity (Greider and Blackburn 1985). The fidelity of reconstituted enzyme activity suggests 

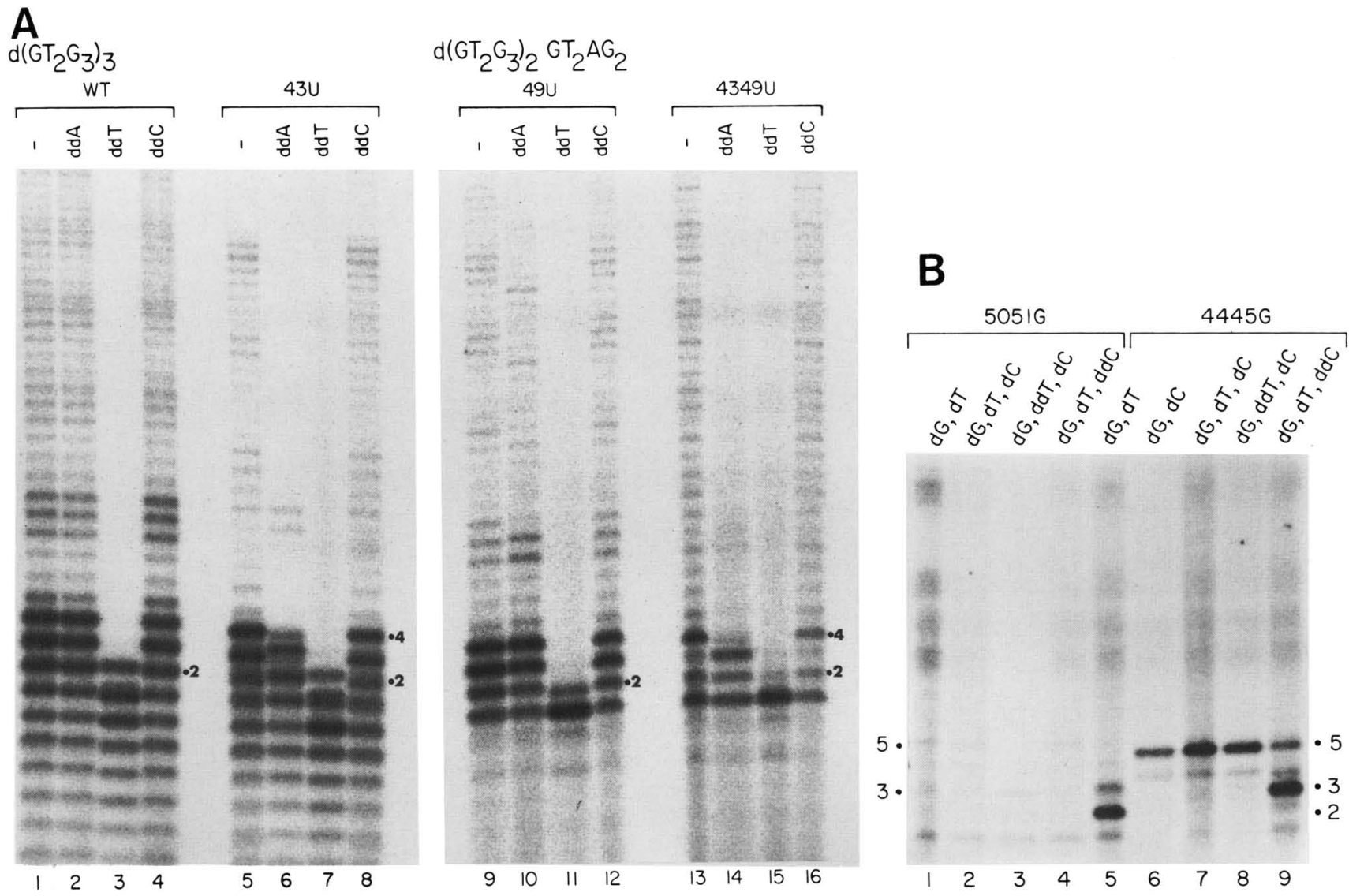

Figure 5. (A) Chain termination upon incorporation of ddATP. Telomerase assays were performed with telomerase pretreated as indicated. Telomerase reconstituted with $200 \mathrm{ng}$ of wild-type telomerase RNA (lanes 1-4), 43U RNA (lanes 5-8), 49U RNA (lanes 9-12), or 4349U RNA (lanes 1316). Elongation reactions were done using

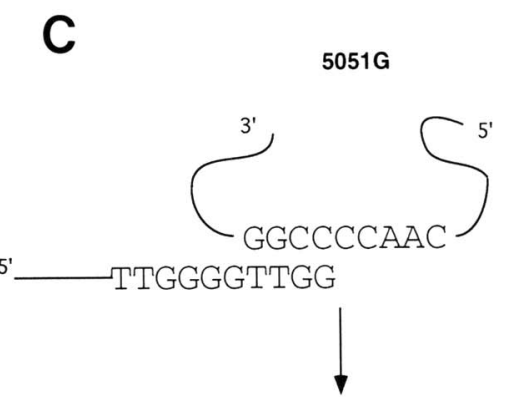

dC not incorporated ddC not incorporated ddT incorporated

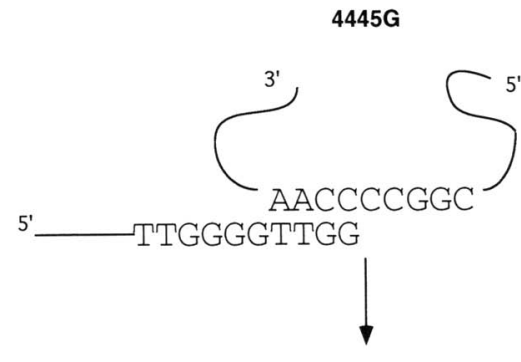

$\mathrm{dC}$ incorporated ddC incorporated ddT not incorporated and ddTTP $($ lanes $3,7,11,15)$, or $\left[\alpha^{-32}\right.$ P]dGTP, dTTP, dATP, and ddCTP (lanes $4,8,12,16$ ) as described. Reconstitution reactions shown in lanes 1-8 and 9-16 were performed with phenyl-Sepharose-purified and DEAE-purified telomerase, respectively. The exposure shown in lanes 1-16 is of a PhosphorAutoradiograph (Fujix BAS 2000 BioImaging Analyzer) photograph from a HQ printer (Fuji). The numbers refer to the number of nucleotides added onto the input primers $(\mathrm{P}) .(B)$ Elongation products of telomerase reconstituted with $4445 \mathrm{G}$ and $505 \mathrm{IG}$ RNAs. (Lanes 1-9) Telomerase reconstituted with $200 \mathrm{ng}$ of 5051G telomerase RNA (lanes 1-4) and 4445G RNA (lanes 5-9). Elongation reactions were done using primer d(GGTTGG) ${ }_{3}$ in the presence of $\left[\alpha^{-32} \mathrm{P}\right] \mathrm{dGTP}$ and dTTP (lanes 1,5$),\left[\alpha^{-32} \mathrm{P}\right] \mathrm{dGTP}$ and dCTP $(1$ ane 6$)$, $\left[\alpha^{-32} \mathrm{P}\right] \mathrm{dGTP}$, dTTP, and dCTP (lanes 2,7), $\left[\alpha-{ }^{32} \mathrm{P}\right] \mathrm{dGTP}$, dCTP, and ddTTP (lanes 3,8), or $\left[\alpha-{ }^{32} \mathrm{P}\right] \mathrm{dGTP}$, dTTP, and ddCTP (lanes 4,9) as described. Reconstitution reactions were performed with phenyl-Sepharose-purified telomerase concentrated on a DEAE-agarose column. $(C)$ The potential alignment of $\mathrm{d}(\mathrm{GGTTGG})_{3}$ primer with the mutant RNA templates $4445 \mathrm{G}$ and $5051 \mathrm{G}$ is shown. The effects of adding dTTP, ddTTP, dCTP, and ddCTP on the elongation of this primer are diagramed. Data are from $B$.

that the reconstitution assay will be a useful biochemical tool for dissecting native telomerase function.

Reconstitution of RNPs generally requires the addition of stoichiometric amounts of RNA and protein nor- mally found in native complexes (Traub and Nomura 1969; Nierhaus and Dohme 1974; Mukheriee and Sarkar 1981; Walter and Blobel 1983). The kinetics and thermodynamics of the protein-RNA interactions in telomerase 
are not yet defined. A typical in vitro telomerase reaction contains $\sim 1 \mathrm{ng}$ of telomerase RNA (Avilion et al. 1992). Reconstitution of telomerase activity, however, required the addition of $\sim 100$-fold more synthetic telomerase RNA over endogenous telomerase RNA. There are several possible explanations for this requirement: lack of potential RNA base modifications of in vitro-transcribed telomerase RNA, inappropriate conformation of the in vitro-transcribed telomerase RNA, and/or nonspecific binding of RNA to MNase (Wang and Gegenheimer 1990).

In other studies, RNPs have been reconstituted with both endogenous and in vitro-transcribed RNA. Reconstitution of $16 \mathrm{~S}$ ribosomal subunits from Escherichia coli with RNA prepared in vitro and lacking modifications normally contained in 16S RNA reduces activity by half (Cunningham et al. 1991). Tetrahymena telomerase RNA may be modified /Greider and Blackburn 1989|. A lack of modifications of in vitro-transcribed telomerase RNA could account for the required concentrations of synthetic RNA for reconstitution of telomerase activity and for the inability, under the conditions described, to restore activity to native levels.

The requirement for 100-fold excess telomerase RNA in reconstitution reactions may also be attributable to the RNA conformation. In vitro assembly experiments have shown that correct folding of rRNA depends on sequential, cooperative interactions with ribosomal proteins (Held et al. 1973; Röhl and Nierhaus 1982). Many features of the higher-order structure of 16S rRNA in 30S ribosomal subunits do not exist in 16S rRNA in its naked form (Moazed et al. 1986). Most of the in vitro-transcribed telomerase RNA added to the reconstitution reactions may assume incorrect conformations that are incapable of associating with telomerase protein(s).

\section{Protein requirement for reconstitution of telomerase activity}

The proteinase $\mathrm{K}$ sensitivity of reconstituted telomerase suggests that proteins are required for reconstitution of telomerase activity (Fig. 2). Whether the telomerase RNA component serves a catalytic or structural role is not yet known. Recent experiments provide evidence that 23S rRNA may catalyze the peptidyl transferase reaction of ribosomes (Noller et al. 1992). Ribosomal proteins are important to achieve proper folding and function of rRNA (Held et al. 1973; Röhl and Nierhaus 1982; Stern et al. 1989). Methods used previously to prepare protein-free rRNA to determine whether rRNA was sufficient for peptidyl transferase activity disturbed the higher order stucture of the rRNA presumably required for this activity (Noller et al. 1992). RNase P activity can be reconstituted without protein in vitro under appropriate ionic conditions; however, protein components are required in vivo, to provide stability, functional binding, and assembly or folding of rRNA /Guerrier-Takada et al. 1983). Thus, although studies to date indicate that protein is essential for native and reconstituted telomerase activity, a direct catalytic role for telomerase RNA in telomere DNA sythesis remains a distinct possibility (Greider and Blackburn 1985, 1987).

\section{Telomerase RNA mutants define distinct functional domains of the RNA template region}

All five telomerase RNA template mutants were functional in the reconstitution of telomerase activity (Figs. $3 \mathrm{~A}$ and $5 \mathrm{~B}$ ). Elongation by telomerase reconstituted with the $4349 \mathrm{U}$ mutant RNA was more processive than with the single $43 \mathrm{U}$ or $49 \mathrm{U}$ mutants; presumably, this efficiency results from having a single mismatch initially between the primer sequence and the RNA template at position 49, and after translocation, no further mismatches (Fig. 3B). In contrast, mismatches would occur repeatedly after each translocation between the $43 \mathrm{U}$ or $49 \mathrm{U}$ mutant templates and the primer or product sequences. Presumably for this reason, the elongation activity of telomerase reconstituted with $43 \mathrm{U}$ or $49 \mathrm{U}$ RNA was not as processive as with $4349 \mathrm{U}$ RNA.

The reconstitution experiments suggest that the $9 \mathrm{nu}$ cleotides of the template region of the telomerase RNA may not all be used as template residues in the elongation of telomeric sequence primers (Figs. 4 and 5). Incorporation of $\left[\alpha^{32} \mathrm{P}\right] \mathrm{dATP}$ by telomerase reconstituted with $43 \mathrm{U}$ or $4349 \mathrm{U}$ RNA indicated that position 43 of these RNAs serves as a template (Fig. 4A). The position of incorporation of $\left[\alpha^{-32} \mathrm{P}\right] \mathrm{dATP}$ from the primer $3^{\prime}$ end by telomerase reconstituted with 43U RNA was dependent on the sequence at the $3^{\prime}$ end of the primers, as predicted by the primer alignment in Figure 4B. Moreover, the nucleotide added to the cleaved d(GGGTTG) primer was dependent on the changed template nucleotide at position 43. Presumably after cleavage of the 3 '-terminal G residue, template-directed addition of $\left[\alpha-{ }^{32} \mathrm{P}\right] \mathrm{dATP}$ generated a labeled product corresponding to the size of the input primer. Chain termination by ddATP or ddTTP, at the predicted positions, further confirmed that the mutant region of $43 \mathrm{U}$ was serving as a template (Fig. 5A). However, telomerase reconstituted with $49 \mathrm{U}$ RNA did not incorporate $\left[\alpha^{32} \mathrm{P}\right] \mathrm{dATP}$ at the concentrations tested, suggesting that position 49 in the template region of telomerase RNA does not serve as a template but may serve to align primer and product sequences (Fig. 4A). Therefore, telomerase reconstituted with $49 \mathrm{U}$ would not be expected to incorporate ddATP. Although ddATP was poorly incorporated by telomerase reconstituted with $49 \mathrm{U}$ RNA, elongation of the telomeric primer d(GTTGGG) $)_{3}$ was partially inhibited, indicating that under certain conditions position 49 may serve as a template (data not shown). Further experiments with RNA mutants $4445 \mathrm{G}$ and $5051 \mathrm{G}$ indicate that positions 44 and 45 also serve as template residues and that positions 50 and 51 probably do not (Fig. 5B). Elongation by telomerase reconstituted with $4445 \mathrm{G}$ RNA was dependent on dCTP and not dTTP and was terminated by the addition of ddCTP and not ddTTP, suggesting that positions 44 and 45 but not 50 and 51 direct the addition of nucleotides. Similarly, elongation by telomerase reconstituted with 5051G RNA was inde- 
pendent of dCTP and was terminated by the incorporation of ddTTP but not ddCTP, reinforcing the role of positions 44 and 45 , but not 50 and 51 , as template nucleotides.

Recent experiments suggest that both RNA and protein sites are involved in telomeric primer binding and recognition by telomerase (Collins and Greider 1993). Both sites may be necessary for binding and alignment of primers. Using a chimeric primer, d(GTTGGG) ${ }_{2}$ GTTAGG, that may ensure optimal binding and alignment to both of these sites in the mutants, elongation by telomerase reconstituted with the $49 \mathrm{U}$ and $4349 \mathrm{U}$ mutants generated a distinct product pattern and was more efficient than elongation of Tetrahymena telomeric sequence primers. Telomerase activity reconstituted with 49U RNA did not incorporate ddATP during elongation of the chimeric primer, suggesting that position 49 in the telomerase RNA does not serve as a template under these conditions (Fig. 5A). Elongation by telomerase reconstituted with $4349 \mathrm{U}$ was terminated because of incorporation of ddATP template-directed by position 43 . The elongation products of telomerase reconstituted with either mutant $4445 \mathrm{G}$ or $5051 \mathrm{G}$ and assayed in the presence of various combinations of dTTP, dCTP, ddCTP, and ddTTP clearly indicate that positions 50 and 51 of the telomerase RNA do not serve as template nucleotides (Fig. 5B). We propose a model in Figure 6 that divides the template region into two functionally distinct regions. In this model, the most $5^{\prime}$ six residues of the telomerase RNA template region, including the residues at positions 43,44 , and 45 direct the addition of telomeric repeat sequences, whereas the most $3^{\prime}$ three residues $(49,50$, and 51$)$ of the template region, may serve only to align substrate or product sequences. We refer to the most $5^{\prime}$ six residues as the "template" and the most 3 ' residues as the "alignment region." Experi-

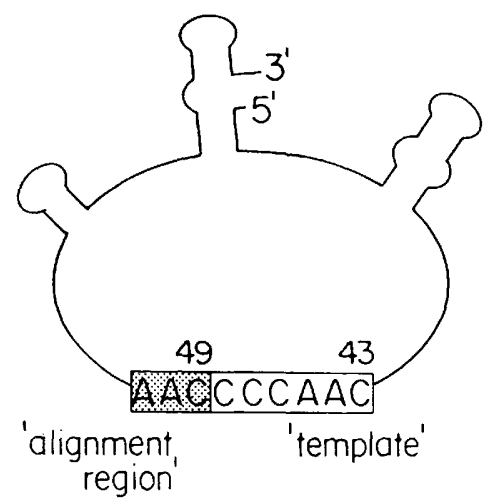

Figure 6. Model for the functional domains of the telomerase RNA template region. The telomerase RNA is shown schematically with the template region $5^{\prime}$-CAACCCCAA-3'. The most $5^{\prime}$ six residues (white box) termed the template direct synthesis of telomeric repeats. The most $3^{\prime}$ three residues (stippled box) termed the alignment region direct the aligment of substrate and product DNA sequences. However, under suboptimal conditions, as discussed in the text, position 49 may be forced to serve as a template position. ments with an RNA template region mutant $\left(5^{\prime}\right.$-CGACCCCAA- $3^{\prime}$ ) in vivo showed that position 44 serves as a template to specify the sequence added by telomerase (Yu et al. 1990), consistent with the hypothesis that residues 43-48 direct the addition of sequences. In addition, an RNA mutant with the template region $5^{\prime}$-CAACCCCCAA-3' specified the synthesis of telomeric $\mathrm{G}_{5} \mathrm{~T}_{2}$ repeats in vivo, indicating that the most $3^{\prime} \mathrm{C}$ residue in the template region, now at position 49 because of the additional $\mathrm{C}$ residue, directs the synthesis of telomeric repeats (Yu and Blackburn 1991). Both in vivo and in vitro reconstitution experiments using other RNA template mutants will be required to further elucidate the role of the residues in this region.

The ability to reconstitute telomerase activity using inactive protein and mutant telomerase RNA will allow the functional dissection of telomerase. The predicted conserved regions of the secondary structure of Tetrahymena telomerase RNAs (Romero and Blackburn 1991) and their importance for function can now be tested directly using reconstitution assays. With the identification of telomerase protein components a thorough understanding of telomerase protein-RNA interactions will be possible.

\section{Materials and methods}

\section{Purification of oligonucleotides}

Oligonucleotides were synthesized by Operon Technologies (Alameda, CA). Oligonucleotides were resuspended in $\mathrm{H}_{2} \mathrm{O}$ treated with diethyl pyrocarbonate (DEPC-treated $\mathrm{H}_{2} \mathrm{O}$ ) and gel purified. An equal volume of oligonucleotide and deionized formamide were mixed, boiled, cooled on ice, and electrophoresed in $12 \%$ polyacrylamide $-7 \mathrm{M}$ urea gels. Full-length primer was identified using UV shadowing (Sambrook et al. 1989). The DNA was excised, crushed, and eluted from the gel by incubation overnight, in DEPC-treated $\mathrm{H}_{2} \mathrm{O}$, at $37^{\circ} \mathrm{C}$. The material eluted from the gel was desalted using Sep-Pak C-18 (Waters) columns, as per the manufacturer's instructions, dried, and resuspended in DEPC-treated $\mathrm{H}_{2} \mathrm{O}$. Oligonucleotide concentrations were determined spectrophotometrically assuming 1 $\mathrm{OD}_{260}$ unit equals $33 \mu \mathrm{g} / \mathrm{ml}$.

\section{Preparation of Tetrahymena telomerase}

Tetrahymena telomerase was purified using protocols modified from Greider and Blackburn (1987), Collins and Greider (1993), and L. Harrington and C. Greider, (unpubl.). Tetrahymena strains SB210 or CU428 [kindly provided by Eric Henderson (Iowa State University, Ames) and Martin Gorovsky (University of Rochester, NY)]) were grown, shaking, at $30^{\circ} \mathrm{C}$, to a density of $2.5 \times 10^{5}$ cells $/ \mathrm{ml}$ in 12 liters of media $(2 \%$ proteose peptone, $0.2 \%$ yeast extract, $10 \mu \mathrm{M} \mathrm{FeCl}$ ) supplemented with $250 \mu \mathrm{g} / \mathrm{l}$ of both ampicillin and streptomycin. After harvesting, the cells were resuspended in Dryls starvation media $1.7 \mathrm{~mm}$ sodium citrate, $2.4 \mathrm{~mm}$ sodium phosphate, $2 \mathrm{~mm} \mathrm{CaCl}$ ) and incubated at $30^{\circ} \mathrm{C}$, for $18 \mathrm{hr}$. Cells were harvested and resuspended in $2 \times$ the volume of the cell pellet, of either TMG $(10 \mathrm{mM}$ Tris-acetate or $-\mathrm{HCl}$ at $\mathrm{pH} 8.0,1 \mathrm{mM} \mathrm{MgCl} 2,10 \%$ glycerol) or PMG (10 mM PIPES at $\mathrm{pH} 7.0,1 \mathrm{~mm} \mathrm{MgCl} 2,10 \%$ glycerol) with 5-10 mM $\beta$-mercaptoethanol, $0.1 \mathrm{mM}$ PMSF, and protease inhibitors $\{0.25$ $\mu \mathrm{g} / \mathrm{ml}$ each chymostatin, leupeptin, antipain, and pepstatin; 
Sigma). Lysis was enhanced by stirring the cells in this buffer, at $4^{\circ} \mathrm{C}$, for $20 \mathrm{~min}$ in the presence of $0.2 \% \mathrm{NP}-40$ (Sigma). The lysed cells were centrifuged at $30,000 \mathrm{rpm}$ for $1 \mathrm{hr}$ in a SW41 rotor at $4^{\circ} \mathrm{C}$, and the supernatant $(\mathrm{S} 100$ extract, $120 \mathrm{ml})$ collected and stored at $-70^{\circ} \mathrm{C}$ after quick freezing in liquid nitrogen.

DEAE-purified telomerase was prepared as follows. Extract $\mathrm{S} 100(120 \mathrm{ml})$ was loaded onto a $40-\mathrm{ml}$ heparin-agarose (BioRad/ column equilibrated in TMG with $\beta$-mercaptoethanol and protease inhibitors as described above. Proteins were eluted in TMG with $0.2 \mathrm{M}$ potassium glutamate (KGlu) and frozen in liquid nitrogen. Fractions containing maximal telomerase activity were loaded on an $8 \mathrm{ml}$ DEAE-agarose (Bio-Rad) column equilibrated in TMG plus $0.2 \mathrm{M} \mathrm{KGlu}$. Proteins were eluted in TMG with a 40-ml gradient from 0-0.6 M KGlu. Fractions with maximal telomerase activity $(0.3-0.4 \mathrm{M} \mathrm{KGlu})$ were pooled $(6$ $\mathrm{ml}$ ), aliquoted, frozen in liquid nitrogen and stored at $-70^{\circ} \mathrm{C}$. DEAE-purified telomerase $(1.3 \mathrm{mg}$ of protein $/ \mathrm{ml}$ extract $)$ was diluted 10-fold with TMG before use in reconstitution reactions.

Alternatively, the $S 100$ extract $(120 \mathrm{ml})$ was loaded directly onto a 9-ml DEAE-agarose column equilibrated in PMG with $\beta$-me and protease inhibitors, and proteins were eluted in PMG with a $45 \mathrm{ml}$ gradient from $0-0.6 \mathrm{M}$ KGlu. Fractions with maximal telomerase activity $(0.3-0.4 \mathrm{M} \mathrm{KGlu})$ were pooled $(5.5 \mathrm{ml})$, adjusted to $0.6 \mathrm{M} \mathrm{KGlu}$, and loaded onto a $5 \mathrm{ml}$ phenyl-Sepharose column (Pharmacia) equilibrated in PMG $0.6 \mathrm{M}$ KGlu. Proteins were eluted with a gradient from PMG $0.6 \mathrm{M}$ KGlu to PM $50 \%$ ethylene glycol. Most of the telomerase activity eluted with PM 50\% ethylene glycol. Fractions with maximal telomerase activity were pooled $(5.5 \mathrm{ml})$, aliquoted, frozen in liquid nitrogen and stored at $-70^{\circ} \mathrm{C}$. The phenyl-Sepharose-purified telomerase $(1.6 \mathrm{mg}$ of protein $/ \mathrm{ml}$ of extract) was used $10-$ fold diluted with PMG in reconstitution reactions. The extract preparations remained active in elongation assays and in reconstitution assays, for at least 17 months when stored at $-70^{\circ} \mathrm{C}$. Protein concentrations were determined by a Bradford assay with Bio-Rad dye reagent.

\section{Telomerase elongation activity assay}

Telomerase assays were done essentially as described previously (Greider and Blackburn 1985). Briefly, $20 \mu \mathrm{l}$ of extract was added to $20 \mu \mathrm{l}$ of a $2 \times$ reaction mix. The final concentrations of the components in the assay are $1 \times$ telomerase buffer $(50 \mathrm{~mm}$ Tris-acetate or $-\mathrm{HCl}$ at $\mathrm{pH} 8.5,1 \mathrm{~mm}$ spermidine, $5 \mathrm{~mm} \beta$-mercaptoethanol, and $50 \mathrm{~mm}$ KOAc), $800 \mathrm{~nm}$ primer oligonucleotide $(0.2 \mu \mathrm{g}), 100 \mu \mathrm{M}$ dTTP, and $0.3125 \mu \mathrm{M}\left[\alpha^{-}{ }^{32} \mathrm{P}\right] \mathrm{dGTP}(1 \mu)$ of 800 $\mathrm{Ci} / \mathrm{mmole}$; NEN). In assays with telomerase reconstituted with mutant RNAs, reaction mixes contained $100 \mu \mathrm{M}$ of both dTTP and dATP. Reactions with $2.5 \mu \mathrm{M}\left[\alpha^{-32} \mathrm{P}\right] \mathrm{dATP} / 4 \mu \mathrm{l}$ of $400 \mathrm{Ci} /$ mmole; NEN) contained $100 \mu \mathrm{M}$ dTTP and $50 \mu \mathrm{M}$ dGTP. In reactions with dideoxynucleotides, ddTTP $(100 \mu \mathrm{M})$ replaced dTTP, ddATP (100 $\mu \mathrm{M})$ replaced dATP, or ddCTP $(20 \mu \mathrm{M})$ was added. Reactions times were $1 \mathrm{hr}$ at $30^{\circ} \mathrm{C}$ except in the experiment shown in Fig. 2 where the incubation time was $20 \mathrm{~min}$. Reactions were stopped by adding $100 \mu \mathrm{l}$ of $21 \mathrm{mM}$ EDTA, 10 $\mathrm{mM}$ Tris- $\mathrm{HCl}$ at $\mathrm{pH} 7.5$. After phenol extraction, $60 \mu 1$ of $2.5 \mathrm{M}$ $\mathrm{NH}_{4} \mathrm{OAc}, 100 \mu \mathrm{g} / \mathrm{ml}$ of $E$. coli tRNA (Sigma) was added to the reactions and ethanol precipitated for $60 \mathrm{~min}$ at room temperature or overnight at $-20^{\circ} \mathrm{C}$. Products were centrifuged, and pellets dried and resuspended in formamide with bromphenol blue (BPB) and xylene cyanol (XC) or formamide with XC. Samples were boiled, cooled on ice, and loaded onto $8 \%$ polyacrylamide $-7 \mathrm{M}$ urea gels and electrophoresed at $1500 \mathrm{~V}$ for $2 \mathrm{hr}$ using $0.6 \times$ TBE buffer. Gels were dried and then exposed to film
(XAR5) overnight (light exposure) or 7-14 days (dark exposure), or Fuji PhosphorImager screens, generally overnight.

\section{MNase treatment and reconstitution assay conditions}

DEAE- or phenyl-Sepharose-purified Tetrahymena telomerase extract was incubated with $1-2$ units of $\mathrm{MNase} / \mu \mathrm{l}$ of extract and 0.1 or $1 \mathrm{mM} \mathrm{CaCl}$, for $10 \mathrm{~min}$ at $30^{\circ} \mathrm{C}$. The MNase was inactivated by adding EGTA $(2.5 \times$ the concentration of added $\mathrm{CaCl}_{2}$ ). MNase was prepared by resuspending the lyophilized material (Boehringer Mannheim) in DEPC-treated $\mathrm{H}_{2} \mathrm{O}$, at a concentration of 50 or $100 \mathrm{U} / \mu \mathrm{l}$, and stored in aliquots at $-20^{\circ} \mathrm{C}$. We found that MNase made in DEPC-treated $\mathrm{H}_{2} \mathrm{O}$, stored in aliquots, thawed, and used only once was the least variable in activity, and this became the preferred method for preparing and storing MNase. Extract treated with MNase was used either immediately or stored, in aliquots, at $-70^{\circ} \mathrm{C}$ (after the addition of EDTA to $5 \mathrm{~mm}$ ) until use. MNase-treated extract was stable at $-70^{\circ} \mathrm{C}$ for at least 4 months. It was important to use only enough MNase to completely abolish telomerase activity, as initially determined by the titration of extract using freshly diluted and aliquoted MNase. Using an excess of MNase decreased the levels of reconstituted activity. In some experiments, telomerase extract was treated with proteinase $\mathrm{K} l 0.2$ $\mu \mathrm{g} / \mu \mathrm{l})$ for $10 \mathrm{~min}$ at $30^{\circ} \mathrm{C}$, prior to MNase treatment. In standard reconstitution conditions, MNase-treated telomerase extract $(\sim 1.5 \mathrm{mg} / \mathrm{ml}$ of protein) was incubated with $5 \mathrm{mM}$ EDTA and 100-200 ng of in vitro-transcribed telomerase RNA per 50 $\mu l$ of extract, for $5 \mathrm{~min}$ at $37^{\circ} \mathrm{C}$. Prior to assaying for elongation activity, $1 \mu \mathrm{l}$ of 200 or $500 \mathrm{mM} \mathrm{MgCl}_{2}$ was added to 20 or $50 \mu \mathrm{l}$ of the extract, respectively.

\section{Site-directed mutagenesis}

The telomerase RNA gene cloned into pUC119 (pCG1; Greider and Blackburn 1989) was subcloned downstream of the T7 promoter. Briefly, oligonucleotides complementary to the $5^{\prime}\left(5^{\prime} \mathrm{T} 7\right)$ and $3^{\prime}\left(3^{\prime} \mathrm{T} 7\right)$ regions of the RNA gene were used in PCR with pCGl cleaved with HindIII, as the template. The sequences of the 5' T7 and 3' T7 oligonucleotides were 5'-GGGGTCTAGATAATACGACTCACTATAGGGATACCCGCTTAATTCATTCA-3' and 5'-CCCCGGATCCAAAAAAAATAAGACATCCATTG-3', respectively, and included, for the $5^{\prime}$ T7 oligonucleotide, the $\mathrm{T} 7$ promoter and a $\mathrm{XbaI}$ restriction site. PCR amplification was done in a $100 \mu \mathrm{l}$ volume in the presence of 1 $\mu \mathrm{M}$ of each primer and $3 \mathrm{ng}$ of HindIII-digested pCGl plasmid DNA using 2.5 units of Taq polymerase (Perkin-Elmer Cetus) in $1 \times$ PCR buffer $150 \mathrm{~mm} \mathrm{KCl}, 10 \mathrm{~mm}$ Tris- $\mathrm{HCl}$ at $\mathrm{pH} 8.3,3 \mathrm{~mm}$ $\mathrm{MgCl}_{2}$ ) and $250 \mu \mathrm{M} \mathrm{dNTPs}$. Reactions were cycled 16 times for $2 \mathrm{~min}$ at $94^{\circ} \mathrm{C}, 3 \mathrm{~min}$ at $37^{\circ} \mathrm{C}$, and $3 \mathrm{~min}$ at $72^{\circ} \mathrm{C}$. The PCRamplified DNA was cleaved with $\mathrm{XbaI}$ and $\mathrm{BamHI}$ and cloned into pUC119 cleaved with BamHI and XbaI using conventional cloning techniques (Maniatis et al. 1982). The resulting clone, pT7159, contained the telomerase RNA gene downstream of the $\mathrm{T} 7$ promoter, as confirmed by sequencing both strands of the inserted DNA by the dideoxy-mediated chain termination method as per the manufacturer's instructions (U.S. Biochemicall.

Using the same methodology, plasmids containing mutant versions of the RNA gene were constructed: Oligonucleotides with mutations complementary to positions 43,49 , both 43 and 49 , both 44 and 45 , or both 50 and 51 of the template region of the RNA gene were synthesized and used in PCR, with pT7159 digested with EcoRI and HindIII, as a template. The sequences of the oligonucleotides were 5'-CATTCAGATCTGTAATAGAACTGTCATTTAACCCCAAAAATC-3' (5'43T), 
5'-CATTCAGATCTGTAATAGAACTGTCATTCAACCCTAAAAATC-3' $\left\{5^{\prime}\right.$ 49' $\}, 5^{\prime}$-CATTCAGATCTGTAATAGAACTGTCATTTAACCCTAAAAATC-3' (5' $\left.^{\prime} 4349 \mathrm{~T}\right), 5^{\prime}$-CATTCAGATCTGTAATAGAACTGTCATTCGGCCCCAAAAATC-3' (4445G), and 5'-CATTCAGATCTGTAATAGAACTGTCATTCAACCCCGGAAATC-3' (5051G). The $3^{\prime}$ T7 oligonucleotide used was the same as described above. PCR conditions were as described above except that $1 \mathrm{ng}$ of plasmid pT7159 digested with EcoRI and HindIII was used. Reactions were cycled 20-30 times for $5 \mathrm{~min}$ at $95^{\circ} \mathrm{C}, 1 \mathrm{~min}$ at $46^{\circ} \mathrm{C}$, and $3 \mathrm{~min}$ at $72^{\circ} \mathrm{C}$. The amplified DNAs were digested with $B a m H I$ and $B g / I I$ (for the $43 \mathrm{~T}, 49 \mathrm{~T}$, and $4349 \mathrm{~T}$ mutants) or EcoRI and BglII (for the 4445G and $5051 \mathrm{G}$ mutants) and cloned into pT7159 digested with the same enzymes. The resulting clones, pT743T, pT749T, pT74349T, pT74445G, and pT75051G, contained mutant RNA genes, as confirmed by sequencing both strands of the entire gene.

\section{Preparation of RNAs}

RNAs used in reconstitution assays were in vitro transcribed with T7 RNA polymerase (Boehringer Mannheim; NEB) using pT7159, pT743T, pT749T, pT74349T, pT74445G, and pT75051G digested with FokI, as templates. Standard in vitro transcription reaction conditions recommended by the T7 RNA polymerase manufacturer were used. The RNAs were either gel purified or the transcription reactions treated with RNase-free DNase (Boehringer Mannheim). The RNA concentrations were determined spectrophotometrically or by fluorometer. The in vitro transcribed RNA was 3 nucleotides longer than the endogenous RNA because of the addition of $3 \mathrm{G}$ residues at the 5' terminus.

\section{Acknowledgments}

We thank Drs. Steve Bell, Kathleen Collins, Adrian Krainer, George Kukolj, and members of the Greider laboratory for helpful discussions and critical reading of this manuscript. We thank Stephanie K. Smith for excellent technical assistance in the construction of pT74445G and pT75051G. C.A. is a fellow of Le Fonds en Recherche et Santé du Québec (Canada). C.W.G. is a Pew Scholar in the Biomedical Sciences. This work was supported by National Institutes of Health grant GM43080 to C.W.G.

The publication costs of this article were defrayed in part by payment of page charges. This article must therefore be hereby marked "advertisement" in accordance with 18 USC section 1734 solely to indicate this fact.

\section{References}

Allsopp, R.C., H. Vaziri, C. Patterson, S. Goldstein, E.V. Younglai, A.B. Futcher, C.W. Greider, and C.B. Harley. 1992. Telomere length predicts the replicative capacity of human fibroblasts. Proc. Natl. Acad. Sci. 89: 10114-10118.

Avilion, A.A., L.A. Harrington, and C.W. Greider. 1992. Tetrahymena telomerase RNA levels increase during macronuclear development. Dev. Genet. 13: 80-86.

Biessmann, H. and J.M. Mason. 1992. Genetics and molecular biology of telomeres. Adv. Genet. 30: 185-249.

Blackburn, E.H. 1991. Structure and function of telomeres. $\mathrm{Na}$ ture 350: 569-573.

Blobel, G. 1971. Isolation of a 5S RNA-protein complex from mammalian ribosomes. Proc. Natl. Acad. Sci. 68: 18811885.
Collins, K. and C.W. Greider. 1993. Tetrahymena telomerase catalyzes nucleolytic cleavage and non-processive elongation. Genes \& Dev. 7: 1364-1376.

Counter, C.M., A.A. Avilion, C.E. LeFeuvre, N.G. Stewart, C.W. Greider, C.B. Harley, and S. Bacchetti. 1992. Telomere shortening associated with chromosome instability is arrested in immortal cells which express telomerase activity. EMBO J. 11: 1921-1929.

Cunningham, P.R., R.B. Richard, C.J. Weitzmann, K. Nurse, and J. Ofengand. 1991. The absence of modified nucleotides affects both in vitro assembly and in vitro function of the $30 \mathrm{~S}$ ribosomal subunit of Escherichia coli. Biochimie 73: 789796.

Greider, C.W. 1991a. Telomerase is processive. Mol. Cell. Biol. 11: $4572-4580$.

1991b. Telomeres. Curr. Opin. Cell Biol. 3: 444-451.

Greider, C.W. and E.H. Blackburn. 1985. Identification of a specific telomere terminal transferase activity in Tetrahymena extracts. Cell 43: 405-413.

- 1987. The telomere terminal transferase of Tetrahymena is a ribonucleoprotein enzyme with two kinds of primer specificity. Cell 51: 887-898.

- 1989. A telomeric sequence in the RNA of Tetrahymena telomerase required for telomere repeat synthesis. Nature 337: 331-337.

Guerrier-Takada, C., K. Gardiner, T. Marsh, N. Pace, and S. Altman. 1983. The RNA moiety of ribonuclease $\mathrm{P}$ is the catalytic subunit of the enzyme. Cell 35: 849-857.

Guthrie, C. and R. Atchison. 1980. Biochemical characterization of RNase P: A tRNA processing activity with protein and RNA components. In Transfer RNA: Biological aspects. (ed. D. Soll, J.N. Abelson, and P.R. Schimmel), pp. 83-97. Cold Spring Harbor Laboratory, Cold Spring Harbor, New York.

Harley, C.B., A.B. Futcher, and C.W. Greider. 1990. Telomeres shorten during ageing of human fibroblasts. Nature 345: $458-460$.

Harrington, L.A. and C.W. Greider. 1991. Telomerase primer specificity and chromosome healing. Nature 353: 451-454.

Hastie, N.D., M. Dempster, M.G. Dunlop, A.M. Thompson, D.K. Green, and R.C. Allshire. 1990. Telomere reduction in human colorectal carcinoma and with ageing. Nature 346: $866-868$.

Held, W.A., S. Mizushima, and M. Nomura. 1973. Reconstitution of Escherichia coli $30 \mathrm{~S}$ ribosomal subunits from purified molecular components. J. Biol. Chem. 248: 5720-5730.

Kole, R. and S. Altman. 1979. Reconstitution of RNase P from inactive RNA and protein. Proc. Natl. Acad. Sci. 76: 37953799.

Lundblad, V. and J.W. Szostak. 1989. A mutant with a defect in telomere elongation leads to senescence in yeast. Cell 57: 633-643.

Maniatis, T., E.F. Fritsch, and J. Sambrook. 1982. Molecular cloning: A laboratory manual. Cold Spring Harbor Laboratory, Cold Spring Harbor, New York.

McClintock, B. 1941. The stability of broken ends of chromosomes in Zea mays. Genetics 26: 234-282.

McPheeters, D.S., P. Fabrizio, and J. Abelson. 1989. In vitro reconstitution of functional yeast $\mathrm{U} 2$ snRNPs. Genes \& Dev. 3: 2124-2136.

Moazed, D., S. Stern, and H.F. Noller. 1986. Rapid chemical probing of conformation in $16 \mathrm{~S}$ ribosomal RNA and $30 \mathrm{~S}$ ribosomal subunits using primer extension. J. Mol. Biol. 187: 399-416.

Morin, G.B. 1989. The human telomere terminal transferase enzyme is a ribonucleoprotein that synthesizes TTAGGG 
repeats. Cell 59: 521-529.

Mukherjee, A.K. and S. Sarkar. 1981. The translational inhibitor $10 S$ cytoplasmic ribonucleoprotein of chick embryonic muscle. J. Biol. Chem. 256: 11301-11306.

Müller, H.J. 1938. The remaking of chromosomes. Collecting Net 13: 181-198.

Newton, I., J. Rinke, and R. Brimacombe. 1975. Random exchange of ribosomal proteins in EDTA sub-particles. FEBS Lett. 51: 215-218.

Nierhaus, K.H. and F. Dohme. 1974. Total reconstitution of functionally active $50 \mathrm{~S}$ ribosomal subunits from Escherichia coli. Proc. Natl. Acad. Sci. 71: 4713-4717.

Noller, H.F., V. Hoffarth, and L. Zimniak. 1992. Unusual resistance of peptidyl transferase to protein extraction procedures. Science 256: 1416-1419.

Olovnikov, A.M. 1973. A theory of marginotomy. J. Theor. Biol. 41: $181-190$.

Prowse, K.R., A.A. Avilion, and C.W. Greider. 1993. Identification of a nonprocessive telomerase activity from mouse cells. Proc. Natl. Acad. Sci. 90: 1493-1497.

Röhl, R. and K.H. Nierhaus. 1982. Assembly map of the large subunit (50S) of Escherichia coli ribosomes. Proc. Natl. Acad. Sci. 79: 729-733.

Romero, D.P. and E.H. Blackburn. 1991. A conserved secondary structure for telomerase RNA. Cell 67: 343-353.

Sambrook, J., E.F. Fritsch, and T. Maniatis. 1989. Molecular cloning: A laboratory manual, 2nd ed. Cold Spring Harbor Laboratory Press, Cold Spring Harbor, New York.

Schenkel, J. and P.M. Kloetzel. 1989. In vitro reconstitution of hnRNP particles. FEBS Lett. 247: 51-54.

Shippen-Lentz, D. and E.H. Blackburn. 1989. Telomere terminal transferase activity from Euplotes crassus adds large numbers of TTTTGGGG repeats onto telomeric primers. Mol. Cell. Biol. 9: 2761-2764.

- 1990. Functional evidence for an RNA template in telomerase. Science 247: 546-552.

Spirin, A.S. 1974. Structural transformation of ribosomes (dissociation, unfolding and disassembly|. FEBS Lett. 40S: S38S47.

Stern, S., T. Powers, L.-M. Changchien, and H.F. Noller. 1989. RNA-protein interactions in 30 S ribosomal subunits: Folding and function of 16S rRNA. Science 244: 783-790.

Traub, P. and M. Nomura. 1969. Structure and function of Escherichia coli ribosomes VI. Mechanism of assembly of $30 \mathrm{~S}$ ribosomes studied in vitro. J. Mol. Biol. 40: 391-413.

Vaziri, H., F. Schaechter, I. Uchida, L. Wei, Z. Xiaoming, R. Effros, D. Choen, and C.B. Harley. 1993. Loss of telomeric DNA during aging of normal and trisomy 21 human lymphocytes. Am. \%. Hum. Genet. 52: 661-667.

Walter, P. and G. Blobel. 1983. Disassembly and reconstitution of signal recognition particle. Cell 34: 525-533.

Wang, M.J. and P. Gegenheimer. 1990. Substrate masking: binding of RNA by EGTA-inactiviated micrococcal nuclease results in artifactual inhibition of RNA processing reactions. Nucleic Acids Res. 18: 6625-6631.

Watson, J.D. 1972. Origin of concatameric T4 DNA. Nature New Biol. 239: 197-201.

Yu, G.-L. and E.H. Blackburn. 1991. Developmentally programmed healing of chromosomes by telomerase in Tetrahymena. Cell 67: 823-832.

Yu, G.-L., J.D. Bradley, L.D. Attardi, and E.H. Blackburn. 1990. In vivo alteration of telomere sequences and senescence caused by mutated Tetrahymena telomerase RNAs. Nature 344: 126-132.

Yuan, Y., E. Tan, and R. Reddy. 1991. The 40-kilodalton To antigen associates with nucleotides 21 to 64 of human mi- tochondrial RNA processing/7-2 RNA in vitro. Mol. Cell. Biol. 11: 5266-5274.

Zahler, A.M. and D.M. Prescott. 1988. Telomere terminal transferase activity in the hypotrichous ciliate Oxytricha nova and a model for replication of the ends of linear DNA molecules. Nucleic Acids Res. 16: 6953-6972.

Zakian, V.A. 1989. Structure and function of telomeres. Annu. Rev. Genet. 23: 579-604. 


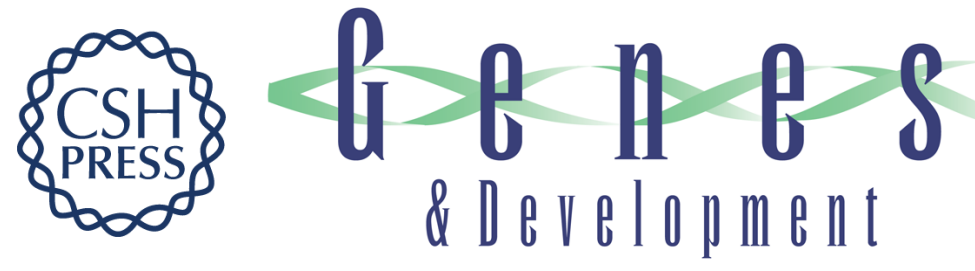

\section{Functional reconstitution of wild-type and mutant Tetrahymena telomerase.}

C Autexier and C W Greider

Genes Dev. 1994, 8:

Access the most recent version at doi:10.1101/gad.8.5.563

References This article cites 48 articles, 17 of which can be accessed free at:

http://genesdev.cshlp.org/content/8/5/563.full.html\#ref-list-1

License

Email Alerting

Service

Receive free email alerts when new articles cite this article - sign up in the box at the top right corner of the article or click here.

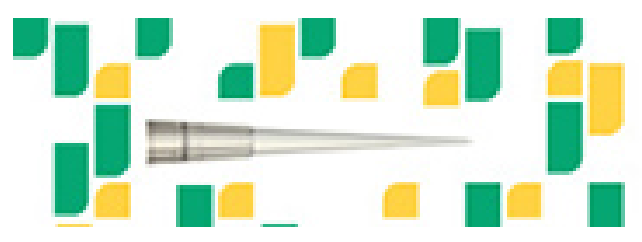

Focused on your science. 